\title{
Prevention of Candida albicans Biofilm Formation
}

\author{
T. Coenye*, K. De Prijck, H. Nailis and H.J. Nelis \\ Laboratory of Pharmaceutical Microbiology, Ghent University, Ghent, Belgium
}

\begin{abstract}
Biofilm formation is often considered to be the underlying reason why treatment with an antimicrobial agent fails and as an estimated $65-80 \%$ of all infections is thought to be biofilm-related, this presents a serious challenge. Considerable attention has been devoted to the development of modified materials that prevent (or at least drastically reduce) microbial biofilm formation. In this review we present an overview of the approaches that have been used to prevent biofilm formation by the fungal pathogen Candida albicans.
\end{abstract}

Keywords: Candida albicans, biofilm, prevention, treatment, impregnation, functionalisation.

\section{MICROBIAL BIOFILMS}

Biofilms are highly structured, hydrated microbial communities containing sessile cells embedded in a self-produced extracelllular polymeric matrix (containing polysaccharides, DNA and other components) [1,2]. In comparison to their planktonic counterparts (i.e. free floating cells in suspension), sessile cells are often much more resistant to antimicrobial agents and this increased resistance has a considerable impact on the treatment of biofilm-related infections [2-5]. Several mechanisms are thought to be involved in biofilm antimicrobial resistance including (i) slow penetration of the antimicrobial agent into the biofilm, (ii) changes in the chemical microenvironment within the biofilm, leading to zones of slow or no growth, (iii) adaptive stress responses, and (iv) presence of a small population of extremely resistant "persister" cells $[2,4,5]$. The development of a biofilm occurs in several distinct phases $[1,2,6]$. Adhesion between cell-surface components and another surface is mediated by reversible hydrophobic and electrostatic forces and microbial attachment is the result of a balance between attraction and repulsion. Adhesion to abiotic surfaces is primarily mediated by hydrophobic interactions, whereas microbial adherence to biological surfaces is controlled by adhesins, e.g. lectins. Adherence is not limited to one single species as most biofilms in nature are polymicrobial [7]. For more information on the pathogenesis of polymicrobial biofilms, the readers are directed to the review of Jabra-Rizk in this special issue. Shortly after colonization, the adhered cells already show an altered phenotype (e.g. reduced motility, increased resistance). Secondly, the cells start to multiply and aggregate into communities. Microcolonies are formed on the surface and these will further develop and form complex, three-dimensional structures. This premature biofilm is anchored to the surface by more irreversible forces such as Van der Waals forces. The subsequent phase is characterized by the production and secretion of polymers, which form the extracellular polymeric substance (EPS). In later stages,

*Address correspondence to this author at Laboratory of Pharmaceutical Microbiology, Ghent University, Ghent, Belgium; Tel: +3292648141; Fax: +3292648195; E-mail: Tom.Coenye@UGent.be micro-organisms can detach from the surface (either as single cells or in aggregates), become planktonic and colonize new surfaces (dispersal of the biofilm). The mature biofilm provides a three-dimensional network of cells entrapped in a polymer matrix on a colonized surface. The organization and structure of a biofilm highly depend on the species involved and the surface on which the biofilm is formed. Several factors affect the formation of a biofilm and its final architecture, including the substrate, the microorganism, oxygen supply, availability of nutrients, the presence of saliva or a conditioning film and the EPS $[6,8,9]$.

\section{RESISTANCE OF BIOFILM CELLS}

Life in a microbial biofilm offers considerable advantages over the planktonic mode of growth. Biofilm cells are significantly more tolerant to antibiotics and biocides. The biofilm provides protection for embedded cells against external stress such as antibacterial and/or antifungal agents and to human defense mechanisms in cases of biofilms formed in the human body. Considerable differences in susceptibility to antimicrobial agents between planktonic and biofilm cells have been reported and various underlying mechanisms for the increased resistance of biofilm cells have been described/proposed. First, environmental gradients within the biofilm structure may result in different antibiotic concentrations reaching the individual cells. Moreover, chemical and $\mathrm{pH}$ gradients may affect the antimicrobial activity $[5,10]$. The increased resistance of biofilm cells has been explained by a delayed penetration of the antimicrobial agent through the biofilm matrix. Antimicrobial agents have to diffuse through the extracellular matrix via water channels in order to reach the cells. The matrix may acts as a barrier to antimicrobial compounds as the target cells are located in the biofilm biomass [11]. In addition, matrix components may also bind antimicrobial agents directly [12-14]. Another hypothesis is that metabolically quiescent sessile cells grow more slowly than their planktonic counterparts, making them refractory to antimicrobial treatment. Furthermore, nutrient limitation and the production of toxic metabolites are thought to favor the formation of a biofilm [15]. Finally, the presence of persisters may underlie the resistance of biofilms to antimicrobials. Persister cells are phenotypic variants of 
wild-type strains and can survive concentrations of antibiotics or antifungal agents far above the MIC [16]. They occur in both planktonic cultures and bacterial biofilms produced by Pseudomonas aeruginosa, Escherichia coli and Staphylococcus aureus [17] and may account for more than $1 \%$ of the population $[18,19]$. Highly antifungal tolerant cells have been identified in Candida albicans biofilms but not in planktonic cell suspensions [20].

\section{BIOFILM FORMATION BY CANDIDA $A L B I C A N S$}

Candida spp. occur as asporogenous yeast cells but can also form hyphae or pseudohyphae under certain conditions [21]. In the human body, Candida species occur as commensals on the skin as well as in the oral cavity, the gastrointestinal tract, the urogenital tract and the vagina [21]. Under certain circumstances these micro-organisms become pathogens and cause infections ranging from superficial mucous membrane infection (candidiasis) to life-threatening systemic diseases [22], particularly in immunocompromised patients with AIDS, cancer and diabetes mellitus [6,23]. Virulence factors of $C$. albicans include proteases, adhesins and the morphological conversion from a budding yeast to a filamentous form. The increasing use of indwelling medical devices in conjunction with an ageing/increasingly immunocompromised population has resulted in a surge of hospital acquired Candida spp. infections, C. albicans ranking high among nosocomial pathogens. Candida infections are frequently associated with the formation of biofilms on implantable medical devices [15]. These devices readily support biofilm formation and are responsible for a considerable percentage of clinical candidiasis cases. Several experimental parameters such as the nature of the surface material [24,25], the growth medium [26,27] and conditions of incubation [28,29] influence $C$. albicans biofilm formation and structure [15]. Chandra et al. studied $C$. albicans biofilm formation on PDMS and polymethylmethacrylate (PMMA) and found that for both polymers biofilm formation typically occurs in three distinct phases, i.e. an early ( 0 to $11 \mathrm{~h})$, intermediate $(12$ to $30 \mathrm{~h})$ and late (12

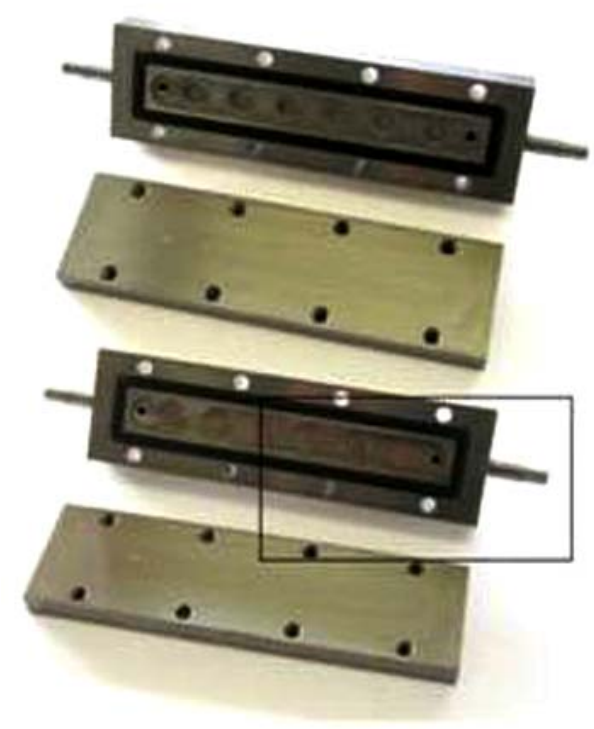

to $30 \mathrm{~h}$ ) phase [30]. The development of a biofilm starts with the adhesion of primarily blastospores (yeast cells) to a surface. This adherence is mediated by non-specific hydrophobic and electrostatic interactions and specific adhesins on the fungal cell surface, e.g. glycoproteins belonging to the agglutinin-like sequence family ( $A L S$ family) [31-34]. The blastospore layer is in close contact with the surface and will anchor the final three-dimensional structure to the colonized substrate. The initial adherence is followed after appr. 3 to 4 $\mathrm{h}$ by the formation of microcolonies on the colonized surface. After $11 \mathrm{~h}$, a thick fungal $C$. albicans growth can be observed. The intermediate phase $(12-24 \mathrm{~h})$ is mainly characterized by the synthesis of the extracellular matrix, covering the $C$. albicans cells of the premature biofilm and increasing with longer incubation times [30]. After 24 to 48 $\mathrm{h}$ of incubation, a complex network of yeast cells, pseudohyphae and true hyphae is established, with the upper layers of the biofilm mainly consisting of hyphae. Mature Candida biofilms show an extensive spatial heterogeneity, with a typical microcolony/water channel architecture and cells embedded in an extracellular polymer matrix. The heterogeneous build-up of mature biofilms allows an influx of water and nutrients and efflux of metabolites/waste products $[35,36]$. Based on non-destructive inspection of the biofilm structure using CLSM, the thickness of mature biofilms has been estimated to range from 25 up to more than $250 \mu \mathrm{m}[30,35]$.

\section{IN VITRO BIOFILM MODEL SYSTEMS}

Several model systems have been described in the literature to grow biofilms in vitro on a variety of surfaces. Basically, these systems can be divided into so-called static (e.g. microtiter plate $[\mathrm{MTP}]$ ) and dynamic (e.g. Modified Robbins Device [MRD] and Centers for Disease Control [CDC] bioreactor) systems.

\section{Microtiterplate (MTP)}

In these systems, biofilms are either grown on the bottom and the walls of the microtiter plate (most commonly a 96-

Fig. (1). Close-up of the Modified Robbins Device (MRD) loaded with PMMA disks. 
well plate) or they are grown on the surface of a coupon placed in the wells of the microtiter plate (most commonly a 6, 12 or 24-well plate) [see for example references 37-40]. Microbial cell suspensions are added to the wells and the plate is incubated to allow adherence of the cells. After the adhesion phase, the cell suspensions are removed and the wells are rinsed to remove non-adherent cells. Finally, growth medium is added and biofilms are allowed to develop [38]. In this high throughput system, biofilms are formed with increasing incubation times but during their formation the growth medium is typically not replaced.

\section{Modified Robbins Device (MRD)}

Unlike static systems, colonized surfaces in a dynamic model system are exposed to a flow of a liquid medium, continuously removed by means of a peristaltic pump. The MRD (Fig. 1) and CDC bioreactor (Fig. 2), are two examples of dynamic biofilm model systems.

The set-up used in our research group consists of six homemade, separate stainless steel devices [41] to study the biofilm formation on disks. Prior to use, the disks are decontaminated (with ethanol) or sterilized (by autoclaving). One MRD contains six individual ports in a linear array along a channel of rectangular cross-section. Each port accepts a press-fit plug holding a disk. The six MRDs, containing the disks (36 in total) are placed in an aluminium heating block. Feedback from a Pt electrode placed in the heating block ensures a constant temperature in the MRDs. The tubing, valves and MRDs are washed, assembled and autoclaved prior to each run. Assembly is done in a Laminar Air Flow cabinet to prevent contamination and the tubing is connected to a peristaltic pump. Bottles either with growth media or inocula are connected to the MRDs and the setup includes a bypass to allow rinsing of the tubing at the inlet side of the devices and the removal of air bubbles. At the outlet side, a clamp placed on the tubing prevents the drainage of the liquid when the pump is switched off (e.g. during adhesion). After introduction of the inoculated solutions into the MRDs, the latter are flipped over to improve the adhesion of the planktonic cells to the disks. Once the devices are filled with the suspensions, the tubing at the inlet and outlet side is clamped off and the remaining cell suspension in the tubing at the inlet side is flushed out through the bypass. After the adhesion, the devices are flipped back, the clamps are loosened and the pump is started to allow a continuous flow of the growth medium and biofilm development on the disks. The set-up of the MRD allows a comparison of biofilms simultaneously grown under various conditions or on different surfaces. Antibiofilm strategies, e.g. strategies to prevent Pseudomonas aeruginosa biofilm formation have been studied in MRDs $[42,43]$. The potential of antibiotic lock therapy to remove biofilms from colonized surfaces has been evaluated in the MRD [44-46]. In the MRD, surfaces releasing active compounds can be tested in parallel without affecting biofilm development on control (unmodified) surfaces. To create a closed circuit, MRDs can be connected to glass vessels, such as a chemostat, in which the micro-organisms are grown continuously before they are introduced in the device [47-51].

\section{Centers for Disease Control (CDC) Biofilm Reactor}

The CDC biofilm reactor (Fig. 2) consists of a glass vessel, in which three coupons (or polymer surfaces containing the developing biofilms) are held by each of eight rods. Each polypropylene rod is adjusted in such a way that the coupon is perpendicular to the rotating baffle [52]. In this reactor, the magnetic stirrer in the center of the vessel provides a continuous flow of nutrients (introduced in the reactor by means of a peristaltic pump) over the colonized surfaces [53]. As all surfaces are exposed to the same growth medium in one and the same bioreactor, this model system

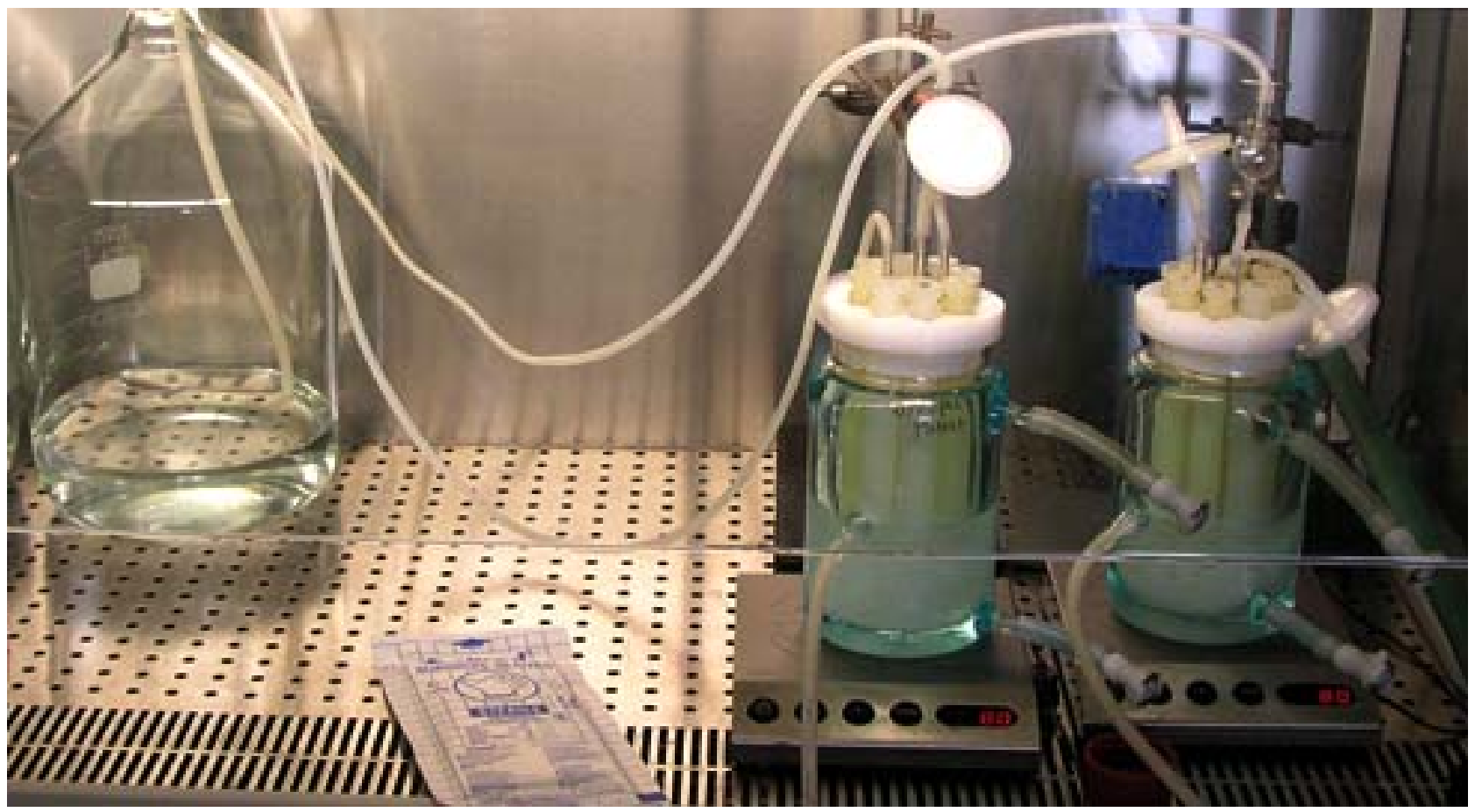

Fig. (2). Set-up of the CDC reactor. 
lends itself very well to monitor biofilm formation as a function of time [54-56].

\section{Calgary Biofilm Device (CBD)}

The Calgary Biofilm device (CBD) is an in vitro biofilm model system which has been extensively used to test the susceptibility of biofilm cells to antibiotics. The CBD has been described by Ceri et al. (2001) and is a 96-well plate based two-part reaction vessel : the top component consists of a lid with 96 pegs, while the bottom part of the vessel serves to channel the flow of growth medium, hence creating a consistent shear force at each biofilm-developing peg site. After biofilm formation, the biofilms on the pegs can be removed by sonication for cell counting or the lid with the biofilm-containing pegs can be introduced in a standard 96well MTP for susceptibility testing. This in vitro biofilm model system has been widely used for studying biofilm formation by one [57] or multiple bacterial species [58], and by Candida spp. [59], as well as for the efficacy testing of disinfectants [60], antibiotics [61] and antimicrobial peptides [62]. The CBD is commercially available as the MBEC assay system to be used for testing the susceptibility of biofilm cells to antibiotics and biocides [63].

\section{IN VIVO BIOFILM MODEL SYSTEMS}

Although in vitro systems are frequently used, they also have their limitations, the major one being that they do not include the interaction between biofilms and the host immune system. In addition, the milieu surrounding the implanted medical device is extremely complex, which makes it difficult to mimic in vivo conditions using in vitro models. Therefore, animal model systems are necessary to study the pathogenesis of $C$. albicans biofilm-related diseases. Several animal models have been developed so far, utilizing rabbits [64], rats [65,66] or mice [67]. The model systems developed to mimick central venous catheter (CVC) infections $[64,65,67]$ involve the placement of a CVC, followed by direct inoculation of $C$. albicans into the lumen of the catheter. In the subcutaneous rat (SCR) model, catheter segments are incubated with $C$. albicans prior to implantation [66]. Nett et al. recently described an in vivo $C$. albicans biofilm denture model in rats [68].

In vivo grown biofilms are structurally similar to biofilms described in vitro, except for the possible presence of host cells in the biofilm. In the CVC rat model it was shown that biofilm formation results in seeding of the kidneys with $C$. albicans, demonstrating that biofilms provide a niche for disseminated disease [65]. Despite the strengths of in vivo model systems, they are expensive, labour intensive and not easy to implement in the laboratory.

\section{SUBSTRATES PRONE TO BIOFILM FORMATION}

Several medical devices have been introduced in the human body. They include indwelling vascular catheters, cardiac pacemakers, artificial heart valves, peritoneal dialysis catheters, prosthetic hips, joints and tracheo-oesophageal voice prostheses (VPs). However, their increased use in healthcare settings has been accompanied by the formation of microbial biofilms at their surface, ultimately resulting in device-related infections. In medical settings, biofilms readily form on polymer substrates such as polydimethylsiloxane (PDMS) (also called "silicone"). PDMS is frequently used in the production of tracheo-oesophageal VPs [69]. Other polymers used in medical devices and susceptible to biofilm development are polyurethane (central venous catheters), natural rubber used for the production of urinary catheters [70] and polymethylmethacrylate (PMMA) in denture acrylics [71]. In addition, bacteria can easily form biofilms on stainless steel surfaces used in the food industry [72]. Infections associated with the use of medical devices can be localized at the site of insertion or be disseminated to the blood (septicaemia) and the organs (e.g. endocarditis). Both diagnosis and treatment of biofilm-associated infections are difficult. Moreover, antimicrobial therapy is usually ineffective [73].

\section{ALBICANS BIOFILMS AND DEVICE-RELATED INFECTIONS}

\section{Introduction}

With an ageing population, the demand for medical devices such as catheters and prostheses has increased considerably over the last years. Commonly used medical devices prone to $C$. albicans colonization and biofilm formation include central venous catheters, joint prostheses, dialysis materials, prosthetic heart valves, pacemakers, central nervous system shunts, urinary catheters, intra-uterine devices, tracheo-oesophageal VPs and dental prostheses (dentures) [15,36,74-76]. Half of all nosocomial infections are associated with the use of medial devices, i.e. the insertion of foreign, indwelling devices into the human body. Medical device related infections are extremely difficult to treat as microbial cells are protected from external influences inside the biofilm structure. Consequently, these infections are often life threatening and can also lead to failure of the device. Often, once a Candida biofilm has been formed in vivo, removal of the device is almost always required to fully eliminate the infection [36].

In Table $\mathbf{1}$ an overview of the relative infection risk associated with implantable devices in or on which Candida spp. biofilms develop frequently is shown [36]. C. albicans and $C$. parapsilosis are the most common cause of fungal biofilms on medical devices.

\section{Tracheo-oesophageal voice prosthesis}

Laryngopharyngectomy or total laryngectomy is the common treatment of laryngeal or hypolaryngeal carcinoma [77]. Malignant tumors of the vocal cords in humans are mostly removed by a total laryngectomy. Voice restoration can be achieved in alaryngeal speakers with oesophageal speech, the use of an electrolarynx and tracheo-oesophageal speech, using an artificial device. In the past few decades, the latter has been the preferred method for voice rehabilitation [78]. In order to restore speech of laryngectomized patients, Blom and Singer have created a tracheo-oesophageal puncture between the posterior wall of the tracheostome and the upper oesophagus, for placement of a VP [79]. This tracheo-oesophageal puncture is also called shunt or fistula. Tracheo-oesophageal speech is produced during expiration, i.e. air from the trachea is shunted into the 
Table 1. Implantable Devices Prone to Formation of Candida spp. Biofilms (Taken from Reference [36])

\begin{tabular}{|c|c|c|c|}
\hline Device & Usage per year in the US & Infection risk $(\%)$ & Species involved \\
\hline Central and peripheral venous catheters & 5 million & $3-8$ & $\begin{array}{c}\text { C. albicans } \\
\text { C. glabrata } \\
\text { C. parapsilosis }\end{array}$ \\
\hline Hemodialysis and peritoneal dialysis catheters & 240,000 & $1-20$ & $\begin{array}{c}\text { C. albicans } \\
\text { C. parapsilosis }\end{array}$ \\
\hline Endotracheal tubes & Millions & $10-25$ & C. albicans \\
\hline Intracardiac prosthetic devices & 400,000 & $1-3$ & $\begin{array}{l}\text { C. albicans } \\
\text { C. glabrata } \\
\text { C. parapsilosis } \\
\text { C. tropicalis }\end{array}$ \\
\hline & & & \\
\hline Neurosurgical shunts & 40,000 & $6-15$ & C. albicans \\
\hline Voice prostheses & thousands & $50-100$ & $\begin{array}{l}\text { C. albicans } \\
\text { C. tropicalis }\end{array}$ \\
\hline Dentures & $>1$ million & $5-10$ & $\begin{array}{l}\text { C. albicans } \\
\text { C. glabrata }\end{array}$ \\
\hline
\end{tabular}

pharynx through the VP containing a one-way silicone valve. Vibration of the oesophageal wall and articulation of the produced sound using the tongue, teeth and lips create artificial tracheo-oesophageal speech. The first VPs were designed as non-indwelling devices, so that they could be removed by the patient for cleaning. The second generation involves the indwelling VPs, including Blom-Singer, Panje, Staffieri, Groningen buttons, Bordeaux and Provox 1 and 2 VPs. They are surgically inserted between the trachea and the oesophagus by an otolaryngologist, under local anaesthesia $[78,80]$. Nowadays Provox VPs are widely used in laryngectomees. Provox 1 VPs are placed in a retrograde manner, which is generally uncomfortable for the patient and which can be complicated in case of stenosis of the pharyngo-oesophageal segment. A Provox $2 \mathrm{VP}$ is inserted in an anterograde manner. Blom-Singer VPs are similarly inserted in the tracheo-oesophageal puncture using a dissolvable gel cap. The Blom-Singer VP has been described in 1979 by Blom and Singer and the Provox VP by Hilgers and Schouwenburg in 1990 [81]. The Provox VP is commonly used in Europe, while the Blom-Singer device is more popular in the US [81]. Leakage around indwelling VPs is found in $13 \%$ up to $27 \%$ of all replacements. Custom fit Blom-Singer VPs with enlarged flanges have been designed to prevent periprosthetic leakage after tracheo-oesophageal voice rehabilitation [82]. In addition, fluid leakage through the valve is one of the most common problems related to the maintenance of the tracheo-oesophageal puncture and the functioning of the VP. Deformities on the VP surface and/or a negative pressure in the oesophagus (due to swallowing) may open the one way valve, so that liquid enters the respiratory tract. All VPs are highly susceptible to colonization by microorganisms, particularly by Candida spp., growing in biofilms on the surface $[83,84]$. Microbial examination of early explanted devices showed a predominance of $C$. albicans, as opposed to $C$. tropicalis isolates for late explanted VPs [85]. These biofilms cause malfunctioning of the valve, an increase in air flow resistance and possibly fluid leakage [86,87]. Consequently, frequent replacement of the VP is necessary [88]. The life span of VPs is different for each patient but generally not more than 3 months.

\section{Dentures}

Candida spp. including $C$. glabrata, $C$. tropicalis and particularly $C$. albicans are frequently recovered from the oral cavity. C. albicans easily colonizes inserted surfaces such as acrylic dentures. There is strong evidence that stomatitis, an infection of the oral mucosa, is associated with the use of dentures in the presence of Candida spp. in the mouth (Candida-associated denture stomatitis) [89]. A proper maintenance of the device and a correct hygiene are prerequisites for the prevention of stomatitis. Mouth rinses containing topical antifungal agents (nystatin or amphotericin B) to treat oral candidosis have limited efficacy. Moreover, they can lead to side effects and recurrent stomatitis if antifungal therapy is discontinued [90-92]. 


\section{PREVENTION OF MICROBIAL BIOFILM BUILD-UP ON POLYMERIC SURFACES}

The resistance of biofilm cells to conventional antibiotics or antifungals has prompted researchers to focus on the nature of the medical device rather than on attempts to remove or kill the micro-organisms. These approaches aim at altering the polymer surface using passive or active strategies for the prevention of biofilm formation.

\section{Passive Antifouling Coatings to Inhibit Surface- Associated Microbial Life}

An early step in the development of a biofilm is the adhesion of bacteria and/or fungi to surfaces, initiated by the interaction between compounds in the cell wall and the surface. Coatings have been developed to alter the physicochemical properties of the surface so that micro-organism/ substrate interactions are reduced or even prevented and that subsequent biofilm development is inhibited [93]. Various polymers have been coated by applying a passive coating, e.g. alkanethiols on gold [94] and fish protein coatings on glass or vinyl plastic coverslips [95]. These coatings are "passive" because their effect is not due to antimicrobially active functional groups [96]. Polymers have also been modified using passive coatings of other polymers, e.g. polyethylene glycol, polyethylene oxide brushes and hydrophilic polyurethanes. However, the efficacy of these approaches is limited because the coatings are rapidly masked by adsorbed conditioning films [96].

\section{Prevention of Biofilm Development by Antimicrobial Compounds Released from Modified Surfaces}

Various antimicrobial compounds have been incorporated in polymers. They include antibiotics [97-101], antifungals $[37,102]$, polyethyleneimines, quaternary ammonium compounds, silver ions or silver nanoparticles [103105], antibodies [106-108] and nitric oxide [96,109-112]. In several studies the in vivo effect of catheters impregnated with antibiotics (often rifampicin) was evaluated (for an extensive review see reference 113). Negatively charged antibiotics can be electrostatically bound to a surface containing an adsorbed cationic surfactant, e.g. tridodecylmethylammonium chloride. The latter is immobilized by hydrophobic interaction between the long alkyl chain of the surfactant and alkyl groups on the surface. In a second procedure for preparing drug impregnated catheters, the antimicrobial compound is incorporated in the polymer by adding it prior to injection molding or extrusion (admixture) [37,114-116]. Finally, polymers can be soaked or dipped in solutions to load the antimicrobial in the polymer network (impregnation). Modified material should release high concentrations of the antimicrobial in early phases, to combat early colonization and preferably sustain this release over a sufficiently long period of time.

The effect of this approach on the ability of C. albicans to form biofilms on silicone was investigated by De Prijck et al. [37]. Biofilm formation on unmodified silicone was compared to biofilm formation on silicone loaded with nystatin (prepared both by admixture and impregnation) and silicone impregnated with miconazole, tea tree oil and zinc pyrithione. Nystatin-medicated silicone disks exhibited a concentration-dependent inhibitory effect on biofilm formation in a MTP but not in a MRD, indicating that a small fraction of free nystatin was released, which killed $C$. albicans cells in the limited volume of a MTP well. In contrast, biofilm inhibition amounted to more than $90 \%$ in the MRD on disks impregnated with miconazole, tea tree oil, and zinc pyrithione. In another study, polyethylene (PE) and polypropylene (PP) were functionalized at their surfaces with cyclodextrins (CDs) [102]. Functionalization with CDs provided $\mathrm{PE}$ and $\mathrm{PP}$ with the capability to incorporate the anti-fungal drug miconazole leading to reduced C. albicans biofilm formation in a MRD (up to $97 \%$ reduction).

\section{Quaternary Ammonium Compound Coatings}

Quaternary ammonium compound (QAC) coatings have been immobilized onto titanium surfaces by immersing the substrates in QAC containing solutions. Results showed an overall reduction of $98.8 \%$ of adhered cells for 4 C. albicans and 2 Streptococcus mutans isolates. Moreover, the results suggested that QAC-titanium exhibited its antimicrobial action through at least two mechanisms. The octadecyl chain inhibited initial adherence and the quaternary ammonium salt resulted in the killing of the cells that did manage to adhere, resulting in delayed or reduced microbial growth [117].

\section{Silver Coatings}

The antimicrobial properties of silver are well documentted and its mechanism of action has been explained in multiple ways. Nucleophilic sulfhydryl, hydroxyl and amino groups present in proteins, enzymes and membranes easily form coordination bonds with silver cations $\left(\mathrm{Ag}^{+}\right)$. This results in the disruption of cell membranes and the loss of essential protein and enzyme functions, finally leading to cell death. Furthermore, silver cations are able to displace other positively charged ions, e.g. zinc $\left(\mathrm{Zn}^{2+}\right)$ and calcium $\left(\mathrm{Ca}^{2+}\right)$ cations, which are crucial for regulating cellular functions. The broad antibacterial spectrum of silver and the rare development of resistance together with its nontoxic effect on mammalian tissues, make it useful for antimicrobial coating of medical devices. Silver has found application in urinary catheters and in the management of wounds and burn wounds (dressings) [118]. Silver sulfadiazine is currently the most widely used topical antimicrobial agent for treatment of burn wounds [119]. Central venous catheters and orthopaedic fixation pins have also been coated with silver and have been shown to reduce adhesion of bacteria in vitro, but not in vivo. These coatings are probably unable to release the oxidized form of silver, which is believed to be responsible for the antibacterial effect. Surfaces coated with metallic silver do not release $\mathrm{Ag}^{+}$. Silver loaded polymers, designed to act as a reservoir of $\mathrm{Ag}^{+}$, are able to release this cation for extended periods of more than three months. Silver ions have been incorporated into polyamide via a melt-mix process [104] and medical grade PDMS has been loaded with organic silver complexes (nanoparticles) [120]. Silver has also been immobilized in various polymers using carriers such as zeolite [121,122] or zirconium phosphate [123]. Zirconium phosphate carrying multivalent silver, having the molecular formula $\mathrm{AgNaZr}_{6}\left(\mathrm{PO}_{4}\right)_{9} \cdot \mathrm{H}_{2} \mathrm{O}$ (with a +2 valence for silver) showed 
both in vitro (susceptibility testing) and in vivo (in a rat burn wound model) a higher antimicrobial effect against various bacteria ( $S$. aureus, $P$. aeruginosa and $E$. coli) than silver sulfadiazine [124]. Roe et al. [120] have modified the surface of central venous catheters with a combination of silver nitrate, a surfactant and tetramethylethylenediamine. These silver nanoparticle coated catheters released silver ions over a period of more than 10 days and prevented biofilm formation by both Gram-positive and Gram-negative bacteria as well as yeasts, including coagulase-negative staphylococci, Enterococcus spp., E. coli, P. aeruginosa, $S$. aureus and C. albicans [120]. Statically grown $72 \mathrm{~h}$ old biofilms were inhibited for 95\% (E. coli), 95\% (S. aureus), 86\% (coagulase-negative staphylococci), 91\% ( $P$. aeruginosa) and $98 \%$ (C. albicans), respectively. To increase the life span of the Blom-Singer tracheo-oesophageal VP, 7\% silver oxide has been incorporated into the silicone matrix of the flap valve. In vivo results indicated a markedly longer mean lifetime of the silver coated VP, increasing from 36 days (uncoated VP) to 110 days [125]. The use of VPs with a valve containing silver oxide would be advantageous for laryngectomized patients requiring a frequent VP replacement due to fungal growth on the one way valve [126].

\section{PREVENTION OF BIOFILM FORMATION ON POLYMERIC SURFACES FUNCTIONALIZED WITH ANTIMICROBIAL GROUPS}

The purpose of covalent binding or grafting is to functionalize a surface, hence providing the material with specific properties such as enhanced hydrophilic, antimicrobial or biocompatible characteristics. Polymeric materials with antimicrobial activities, so called polymeric biocides can be prepared in different ways. A first method consists of synthesizing polymers with biocidal functional groups at their surface, e.g. by covalent binding of antimicrobial moieties on a preformed polymer network (grafting). The methods used can be plasma-induced or photo-induced polymerization or covalent binding using amino moieties. The second method is copolymerization. The antimicrobials are covalently bound to a surface by adding them as a block monomer during the polymerization process (see Table $\mathbf{2}$ ).

\section{Covalent Binding of Antimicrobial Moieties on a Preformed Polymer}

Photo-induced grafting or photo-induced polymerization has gained a prominent place in surface modification, i.e. for the functionalization of polymeric materials. This technique

Table 2. Examples of Functionalized Surfaces with Activity Against $C$. albicans

\begin{tabular}{|c|c|c|c|c|c|c|}
\hline Compound & Substrate & Procedure & Organism & \multicolumn{2}{|c|}{ Evaluation of the effect } & Refs. \\
\hline & & & & $\begin{array}{l}\text { Non-biofilm }{ }^{\mathrm{a}} \\
(\% \text { reduction })\end{array}$ & $\begin{array}{c}\text { Biofilm }^{\mathrm{b}} \\
(\% \text { reduction })\end{array}$ & \\
\hline $\begin{array}{c}\text { 3-(trimethoxysilyl)propyl } \\
\text { dimethyloctadecyl } \\
\text { ammonium }\end{array}$ & Silicone & $\begin{array}{l}\text { Argon plasma } \\
\text { polymerization }\end{array}$ & $\begin{array}{l}\text { C. tropicalis } \\
\text { C. albicans } \\
\text { Bacteria }\end{array}$ & - & \begin{tabular}{|c|} 
Parallel plate flow \\
chamber \\
$(64 \%$ total \\
bacteria] $)$ \\
$(88 \%$ [total yeast] $)$
\end{tabular} & {$[144]$} \\
\hline Fluoroalkyltrichlorosilanes & Silicone & $\begin{array}{l}\text { Argon plasma } \\
\text { polymerization }\end{array}$ & $\begin{array}{l}\text { C. tropicalis } \\
\text { C. albicans } \\
\text { Bacteria }\end{array}$ & - & $\begin{array}{l}\text { Parallel plate flow } \\
\text { chamber } \\
(<90 \%)\end{array}$ & {$[145]$} \\
\hline N-alkylated PEI & $\begin{array}{l}\text { Cotton, wool, nylon, } \\
\text { PET, glass slides with } \\
\text { amino groups }\end{array}$ & Acylation & $\begin{array}{l}\text { C. albicans } \\
\text { S. cerevisiae } \\
\quad \text { Bacteria }\end{array}$ & $\begin{array}{l}\text { Agar overlay } \\
\text { method } \\
(90-99 \%)\end{array}$ & - & {$[146]$} \\
\hline Peptides (homopolymers) & Silicone & Coupling with AFB & C. albicans & - & MRD (up to $93 \%$ ) & {$[141]$} \\
\hline $\begin{array}{l}\text { Peptides (salivary peptide histatin } 5 \text { and } \\
\text { synthetic variants Dhvar } 4 \text { and Dhvar } 5 \text { ) }\end{array}$ & Silicone & Coupling with AFB & C. albicans & - & MRD (up to $96 \%$ ) & {$[141]$} \\
\hline QAP & $\begin{array}{c}\text { Linear copolymer } \\
\text { CEVE + VBC }\end{array}$ & Copolymerization & $\begin{array}{l}\text { C. albicans } \\
\text { Bacteria }\end{array}$ & $\begin{array}{l}\text { Cut plug method } \\
\text { Survival ratio } \\
\text { C. albicans } \\
(71-100 \%)\end{array}$ & - & {$[143]$} \\
\hline QAP & $\begin{array}{c}\text { Crosslinked copolymer } \\
\mathrm{MMA}+\mathrm{VBC}+\mathrm{DVB} \\
\mathrm{CEVE}+\mathrm{VBC}+\mathrm{DVB}\end{array}$ & Copolymerization & $\begin{array}{c}\text { C. albicans } \\
\text { Bacteria }\end{array}$ & $\begin{array}{l}\text { Cut plug method } \\
\text { Survival ratio } \\
\text { C. albicans } \\
(100 \%)\end{array}$ & - & {$[142]$} \\
\hline $\begin{array}{c}\text { Quaternised } \\
\text { dimethylaminoethylmethacrylate }\end{array}$ & Silicone & Grafting & C. albicans & - & MRD (up to $92 \%$ ) & {$[140]$} \\
\hline Quaternised PEI & Silicone & Grafting & C. albicans & - & MRD (up to $74 \%$ ) & {$[140]$} \\
\hline Quaternised PEI & PMMA & Grafting & C. albicans & - & MRD (up to $74 \%$ ) & {$[140]$} \\
\hline
\end{tabular}

${ }^{\mathrm{a}}$ : procedures not involving growth in a biofilm model system

${ }^{\mathrm{b}}$ : procedures involving growth in a biofilm model system effects are expressed as percent or log reduction.

Abbreviations: PET : polyester [poly(ethylene terephtalate)]; ATRP : atom transfer radical polymerization, QAP : quaternary ammonium and phosphonium compounds, CEVE: chloroethylvinylether; VBC : vinylbenzylchloride ; MMA : methylmethacrylate ; DVB : divinylbenzene ; MPC : 2-methacryloyloxyethyl phosphorylcholine ; AFB : 4-azido-2,3,5,6tetrafluoro-benzoic acid 
allows the introduction of graft chains to a polymer without changing its bulk properties [127]. For surface modification, various polar, hydrophilic monomers have been grafted onto hydrophobic surfaces, such as polyolefins using photoinitiated polymerization. These hydrophilic monomers include acrylic acid, hydroxypropyl acrylate, methacrylic acid and methylmethacrylate [128]. Another method for grafting polymer chains, containing the biocide onto polymeric materials is plasma-induced graft polymerization. Poly(2-methacryloyloxyethyl phosphorylcholine) has been grafted onto the surface of PDMS using argon plasma as an activator of the surface [129] and onto the surface of Co-CrMo alloys using oxygen plasma [130]. Oxygen and atmospheric plasma were used to graft acrylic acid or vinyl sulfonic acid onto solvent cast chitosan membranes [131] and polyethylene terephthalate [132]. Copper metallization (using poly[4-vinylpyridine] as metal ion trapping polymer) of polytetrafluoroethylene surfaces was carried out using helium plasma to design the interface of electronic devices [133]. Other examples of plasma-induced polymerization include graftings onto PDMS [134], polytetrafluoroethylene membranes [135], polyvinylidene surfaces [136] or polyurethanes [137]. An oxalate degrading enzyme, i.e. oxalate oxidase has also been covalently bound to PDMS. It was hypothesized that the enzymatic activity of oxalate oxidase could reduce the amount of oxalate crystals near the PDMS surface, hence preventing calcium oxalate crystal formation and subsequent encrustation of urinary catheters [138]. Various microbicidal surfaces have been synthesized by introducing positively charged groups on glass slides or nanoparticles. To this end, alkylated polyethyleneimines (PEIs) have been coupled by acylation to glass slides containing amino groups [139]. N-alkylated PEI containing glass showed a high bactericidal efficacy (93\%) against airborne $S$. aureus with the highest reduction observed for octadecyl derivatized PEI moieties [139]. De Prijck et al. [140] evaluated whether quaternised PEI covalently bound to silicone or PMMA could reduce C. albicans biofilm formation. Although the use of $\mathrm{C} 1$ or C4-quaternised PEI reduced biofilm formation to some extent (reductions ranging from 35 to $74 \%$ ), reductions were lower than expected based on sensitivity of planktonic cells. Several cationic peptides were covalently bound to silicone by De Prijck et al. [141]. The salivary peptide histatin 5 and two synthetic variants (Dhvar 4 and Dhvar 5), as well as polylysine, polyarginine, and polyhistidine were used to prepare peptide functionalized silicone surfaces. Dhvar 4 functionalized silicone yielded the highest reduction of the number of sessile $C$. albicans cells in the MRD. Poly-D-lysine PDMS, in particular the homopeptides with low molecular weight $(2500$ and 9600) showed the highest activity against $C$. albicans biofilms, with reductions of $93 \%$ and $91 \%$, respectively. De Prijck et al. [140] covalently bound dimethylaminoethylmethacrylate (DMAEMA) and PEI moieties to silicone and PMMA surfaces and subsequently and subsequently quaternized these moieties. Covalently bound quaternized polyDMAEMA and PEI inhibited $C$. albicnas biofilm growth, with reductions up to $92 \%$.

\section{Copolymerization}

In copolymerization, a polymerizable monomer, which contains the biocide is mixed with another monomer. Most attention has been paid to the polymeric quaternary "onium" salts. Both phosphonium and ammonium containing copolymers have been prepared $[142,143]$. A series of compolymers (Fig. 3) derived from the monomer dimethylaminoethylmethacrylate with four different hydrophobic monomers (ethyl, butyl, cyclohexyl, octyl methacrylates) has been synthesized using free radical copolymerization with azobisisobutyronitrile (or benzophenone) at a temperature of $60^{\circ} \mathrm{C}$. The resulting copolymer was further modified with 1,3 propanesulfone to yield polysulfopropylbetaine derivatives. Broth dilution methods showed antibacterial activities against $S$. aureus and $E$. coli, with MIC values ranging from 1125 to $2000 \mu \mathrm{g}$ per $\mathrm{ml}$.

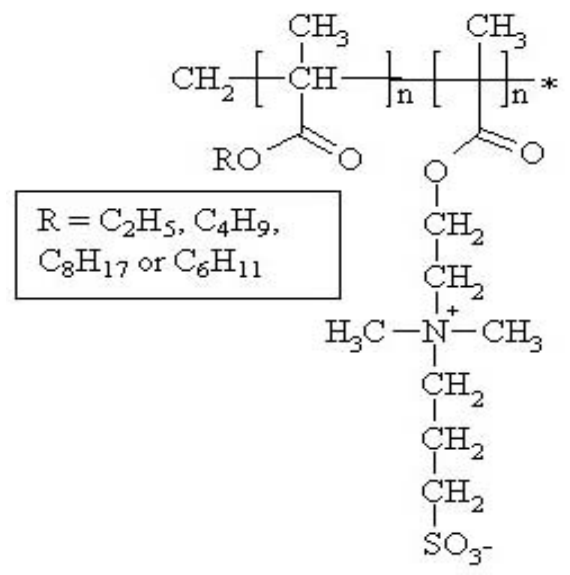

Fig. (3). Copolymer consisting of 2-dimethylaminoethylmethacrylate, with different hydrophobic methacrylate monomers (inset).

\section{CONCLUDING REMARKS}

Prevention or reduction of biofilm formation by antimicrobial compounds covalently bound to a surface requires that the antimicrobial moieties are effectively immobilized, densily grafted, remain stably bound to the surface long enough and are available to cells that freshly adhere to the surface (i.e. are not "masked" by the build-up of a layer of dead cells). The number of new candidate molecules for covalent binding to polymers is restricted, as several anionic, cationic, hydrophilic and hydrophobic compounds immobilized on polymers have previously been studied. Grafting of antimicrobially active compounds is preferred over their incorporation in the polymer as biofilm development is a process which occurs at the surface and not in the bulk. The overall reductions of the number of sessile cells in a biofilm are usually not higher than $90 \%$. However, further research is needed to increase the density of antimicrobial compounds on the surface. In addition, antibiofilm effects will have to be determined not only against monospecies biofilms but also against biofilms consisting of more than one microbial species. Cytotoxicity tests are necessary to demonstrate that the modified substrates are not toxic when introduced in patients. Besides using grafting strategies, polymers can be modified by incorporation of compounds in the bulk polymer. For this purpose, solvent-based approaches are mostly used which may result in residues inside the polymer. Innovative impregnation approaches should focus on solvent-free approaches (e.g. using supercritical carbon dioxide). 


\section{ACKNOWLEDGEMENTS}

We want to thank co-workers and colleagues (past and present) for their valuable contributions and the FWOVlaanderen for financial support.

\section{REFERENCES}

[1] Costerton JW, Lewandowski Z, Caldwell DE, Korber DR, LappinSchott HM. Microbial biofilms. Annu Rev Microbiol 1995; 49: 711- 45.

[2] Donlan RM, Costerton JW. Biofilms: survival mechanisms of clinically relevant microorganisms. Clin Microbiol Rev 2002; 15: 167- 93.

[3] Fux CA, Costerton JW, Stewart PS, Stoodley P. Survival strategies of infectious biofilms. Trends Microbiol 2005; 13: 34-40.

[4] Mah TF, O'Toole GA. Mechanisms of biofilm resistance to antimicrobial agents. Trends Microbiol 2001; 9: 34- 9.

[5] Stewart PS, Costerton JW. Antibiotic resistance of bacteria in biofilms. Lancet 2001; 358: 135-8.

[6] Seneviratne CJ, Jin L, Samaranayake LP. Biofilm lifestyle of Candida: a mini-review. Oral Dis 2008; 14: 582- 90.

[7] Dunne WM. Bacterial adhesion: seen any good biofilms lately. Clin Microbiol Rev 2002; 15: 155- 66.

[8] Macassey E, Dawes P. Biofilms and their role in otorhinolaryngological disease. J Laryngol Otol 2008; 122: 12738.

[9] Das T, Sharma PK, Busscher HJ, van der Mei HC, Krom BP. Role of extracellular DNA in initial bacterial adhesion and surface aggregation. Appl Environ Microbiol 2010; 76: 3405-8.

[10] Stewart PS, Franklin MJ. Physiological heterogeneity in biofilms. Nat Rev Microbiol 2008; 6: 199-210

[11] Gordon CA, Hodges NA, Marriott C. Antibiotic interaction and diffusion through alginate and exopolysaccharide of cystic fibrosisderived Pseudomonas aeruginosa. J Antimicrob Chemother 1988; 22: 667- 4 .

[12] Nett J, Lincoln L, Marchillo K, et al. Putative role of beta-1,3 glucans in Candida albicans biofilm resistance. Antimicrob Agents Chemother 2007; 51: 510-20.

[13] Nett JE, Sanchez H, Cain MT, Andes DR. Genetic basis of Candida biofilm resistance due to drug-sequestering matrix glucan. $\mathrm{J}$ Infect Dis 2010; 202: 171-5.

[14] Sadovskaya I, Vinogradov E, Li J, Hachani A, Kowalska K, Filloux A. High-level antibiotic resistance in Pseudomonas aeruginosa biofilm: the ndvB gene is involved in the production of highly glycerol-phosphorylated beta-(1->3)-glucans, which bind aminoglycosides. Glycobiology 2010; 20: 895-904

[15] Kumamoto CA. Candida biofilms. Curr Opin Microbiol 2002; 5: 608-11.

[16] Lewis K. Multidrug tolerance of biofilms and persister cells. Curr Top Microbiol 2008; 322: 107- 31.

[17] Shah D, Zhang ZG, Khodursky A, Kaldalu N, Kurg K, Lewis K. Persisters: a distinct physiological state of E. coli. BMC Microbiol 2006; 6: 53.

[18] Keren I, Kaldalu N, Spoering A, Wang YP, Lewis K. Persister cells and tolerance to antimicrobials. FEMS Microbiol Lett 2004; 230: 13-8.

[19] Keren I, Shah D, Spoering A, Kaldalu N, Lewis K. Specialized persister cells and the mechanism of multidrug tolerance in Escherichia coli. J Bacteriol 2004; 186: 8172-80.

[20] LaFleur MD. Kumamoto CA, Lewis K. Candida albicans biofilms produce antifungal-tolerant persister cells. Antimicrob Agents Chemother 2006; 50: 3839-46.

[21] McCullough MJ, Ross BC, Reade PC. Candida albicans: a review of its history, taxonomy, epidemiology, virulence attributes, and methods of strain differentiation. Int J Oral Maxillofac Surg 1996; 25: $136-44$.

[22] Samaranayake LP, MacFarlane TW. Oral Candidosis. London: Wright-Butterworth 1990

[23] Edmond MB, Wallace SE, McClish DK, Pfaller MA, Jones RN, Wenzel RP. Nosocomial bloodstream infections in United States hospitals: a three-year analysis. Clin Infect Dis 1999; 29: 239-44.

[24] Hawser SP, Douglas LJ. Biofilm formation by Candida species on the surface of catheter materials in vitro. Infect Immun 1994; 62: $915-21$.
[25] Chandra J, Patel JD, Li J, et al. Modification of surface properties of biomaterials influences the ability of Candida albicans to form biofilms. Appl Environ Microbiol 2005; 71: 8795-801.

[26] Krom BP, Cohen JB, McElhaney Feser GE, Cihlar RL. Optimized candidal biofilm microtiter assay. J Microbiol Meth 2007; 68: 4213.

[27] Jin Y, Samaranayake LP, Samaranayake Y, Yip HK. Biofilm formation of Candida albicans is variably affected by saliva and dietary sugars. Arch Oral Biol 2004; 49: 789-98.

[28] Millsap KW, Bos R, Busscher HJ, Van der Mei HC. Surface aggregation of Candida albicans on glass in the absence and presence of adhering Streptococcus gordonii in a parallel-plate flow chamber: a surface thermodynamical analysis based on acidbase interactions. J Colloid Interf Sci 1999; 212: 495-502.

[29] Gallardo-Moreno AM, Gonzalez-Martin ML, Perez-Giraldo C, Bruque JM, Gomez-Garcia AC. The measurement temperature: an important factor relating physicochemical and adhesive properties of yeast cells to biomaterials. J Colloid Interf Sci 2004; 271: 351-8.

[30] Chandra J, Kuhn DM, Mukherjee PK, Hoyer LL, McCormick T, Ghannoum MA. Biofilm formation by the antifungal pathogen Candida albicans: development, architecture, and drug resistance. J Bacteriol 2001; 183: 5385-94.

[31] Hoyer LL, Green CB, Oh S-H, Zhao X. Discovering the secrets of the Candida albicans agglutinin-like sequence (ALS) gene familya sticky pursuit. Med Mycol 2008; 46: 1-15.

[32] Argimón S, Wishart JA, Leng R, et al. (Developmental regulation of an adhesion gene during cellular morphogenesis in the fungal pathogen Candida albicans. Eukaryotic Cell 2007; 6: 682-92.

[33] Zhao X, Daniel KJ, Oh S-H, et al. Candida albicans Als3p is required for wild-type biofilm formation on silicone elastomer surfaces. Microbiology 2006; 152: 2287-99.

[34] Nobile CJ, Schneider HA, Nett JE, et al. Complementary adhesion function in C. albicans biofilm formation. Curr Biol 2008; 18: 1017-24.

[35] Ramage G, Vande Walle K, Wickles BL, López-Ribot JL. Biofilm formation by Candida dubliniensis. J Clin Microbiol 2001; 39: 3234-40.

[36] Ramage G, Martínez JP, López-Ribot JL. Candida biofilms on implanted biomaterials: a clinically significant problem. FEMS Yeast Res 2006; 6: 979-86.

[37] De Prijck K, De Smet N, Honraet K, Christiaen S, Coenye T. Formation by antimycotics released from modified polydimethyl siloxane. Mycopathologia 2010; 169: 167-74.

[38] Peeters E, Nelis HJ, Coenye T. Comparison of multiple methods for quantification of microbial biofilms grown in microtiter plates. J Microbiol Meth 2008; 72: 157-65.

[39] Vandenbosch D, Braeckmans K, Nelis HJ, Coenye T. Fungicidal activity of miconazole against Candida spp. biofilms. J Antimicrob Chemother 2010; 65: 694-700.

[40] Duggan JM, Sedgley CM. Biofilm formation of oral and endodontic Enterococcus faecalis. J Endodontics 2007; 33: 815-8.

[41] Honraet K, Nelis HJ. Use of the modified robbins device and fluorescent staining to screen plant extracts for the inhibition of S. mutans biofilm formation. J Microbiol Methods 2006; 64: 217-24.

[42] Tang RJ, Cooney JJ. Effects of marine paints on microbial biofilm development on three materials. J Ind Microbiol Biotechnol 1998; 20: 275-80.

[43] Bagge N, Ciofu O, Skovgaard LT, Høiby N. Rapid development in vitro and in vivo of resistance to ceftazidime in biofilm-growing Pseudomonas aeruginosa due to chromosomal $\beta$-lactamase. APMIS 2000; 108: 589-600.

[44] Kumon H, Ono N, Iida M, Nickel JC. Combination effect of fosfomycin and ofloxacin against Pseudomonas aeruginosa growing in a biofilm. Antimicrob Agents Chemother 1995; 39: $1038-44$

[45] Curtin J, Cormican M, Fleming G, Keelehan J, Colleran E. Linezolid compared with eperezolid, vancomycin and gentamicin in an in vitro model of antimicrobial lock therapy for Staphylococcus epidermidis central venous catheter-related biofilm infections. Appl Environ Microbiol 2003; 47: 3145-8.

[46] Raad I, Hanna H, Dvorak T, Chaiban G, Hachem R. Optimal antimicrobial catheter lock solution using different combinations of minocycline, EDTA and 25-percent ethanol, rapidly eradicates organisms embedded in a biofilm. Antimicrob Agents Chemother 2007; 51: 78-83 
[47] Whiteley M, Brown E, McLean RJC. An inexpensive chemostat apparatus for the study of microbial biofilms. J Microbiol Meth 1997; 30: 125-32.

[48] Hughes KA, Sutherland IW, Jones MV. Biofilm susceptibility to bacteriophage attack: the role of phage-borne polysaccharide depolymerase. Microbiology 1998; 144: 3039-47.

[49] Adams JL, McLean RJC. Impact of rpoS deletion on Escherichia coli biofilms. Appl Environ Microbiol 1999; 65: 4285-7.

[50] Corbin BD, McLean RJC, Aaron GM. Bacteriophage T4 multiplication in a glucose-limited Escherichia coli biofilm. Can J Microbiol 2001; 47: 680-4.

[51] Elvers KT, Leeming K, Lappin-Scott HM. Binary culture biofilm formation by Stenotrophomonas maltophilia and Fusarium oxysporum. J Ind Microbiol Biotechnol 2001; 26: 178-83.

[52] Buckingham-Meyer K, Goeres DM, Hamilton MA. Comparative evaluation of biofilm disinfectant efficacy tests. J Microbiol Meth 2007; 70: 236-44.

[53] Goeres DM, Loetterle LR, Hamilton MA, Murga R, Kirby DW, Donlan RM. Statistical assessment of a laboratory method for growing biofilms. Microbiol 2005; 151: 757-62.

[54] Nailis H, Coenye T, Van Nieuwerburgh H, Deforce D, Nelis HJ. Development and evaluation of different normalization strategies for gene expression studies in Candida albicans biofilms by realtime PCR. BMC Mol Biol 2006; 7: 25.

[55] Honraet K, Goetghebeur E, Nelis HJ. Comparison of three assays for the quantification of Candida biomass in suspension and CDC reactor grown biofilms. J Microbiol Meth 2005; 63, 287-95.

[56] Nailis H, Vandenbroucke R, Tilleman K, Deforce D, Nelis HJ, Coenye T. Monitoring ALS1 and ALS3 gene expression during in vitro Candida albicans biofilm formation under continuous flow conditions. Mycopathologia 2009; 167: 9-17.

[57] Ceri H, Olson ME, Stremick C, Read RR, Morck D, Buret A. The Calgary biofilm device: new technologies for rapid determination of antibiotic susceptibilities of bacterial biofilms. J Clin Microbiol 1999; 37: 1771-6

[58] Tomlin KL, Coll OP, Ceri H. Interspecies biofilms of Pseudomonas aeruginosa and Burkholderia cepacia. Can J Microbiol 2001; 47: 949-54.

[59] Parahitiyawa NB, Samaranayake YH, Samaranayake LP, et al. Interspecies variation in Candida biofilm formation studied using the Calgary biofilm device. APMIS 2006; 114: 298-306.

[60] Ali L, Khambaty F, Diachenko G. Investigating the suitability of the Calgary Biofilm Device for assessing the antimicrobial efficacy of new agents. Bioresource Technol 2006; 97: 1887-93.

[61] Sandoe JAT, Wysome J, West AP, Heritage J, Wilcox MH. Measurement of ampicillin, vancomycin, linezolid and gentamicin activity against enterococcal biofilms. J Antimicrob Chemother 2006; 57: 767-70

[62] Harrison JJ, Ceri H, Yerly J, et al. The use of microscopy and three-dimensional visualization to evaluate the structure of microbial biofilms cultivated in the Calgary Biofilm Device. Biol Proced Online 2006; 8: 194-215.

[63] Ceri H, Olson M, Morck D, et al. The MBEC assay system: multiple equivalent biofilms for antibiotic and biocide susceptibility testing. Methods Enzymol 2001; 337: 377-85.

[64] Schinabeck M, Long LA, Hossain MA, et al. Rabbit model of Candida albicans biofilm infection: liposomal amphotericin B antifungal lock therapy. Antimicrob Agents Chemother 2004; 48: 1727-32.

[65] Andes D, Nett J, Oschel P, Albrecht R, Marchillo K, Pitula A. Development and characterization of an in vivo central venous catheter Candida albicans biofilm model. Infect Immun 2004; 72: 6023-31.

[66] Ricicová M, Kucharíková S, Tournu H, et al. Candida albicans biofilm formation in a new in vivo rat model. Microbiology 2010; 156: 909-19.

[67] Lazzell, AL, Chaturvedi, AK, Pierce CG, Prasad D, Uppuluri, P, Lopez-Ribot JL. Treatment and prevention of Candida albicans biofilms with caspofungin in a novel central venous catheter murine model of candidiasis. J Antimicrob Chemother 2009; 64: 567-70.

[68] Nett JE, Marchillo K, Spigel CA, Andes DR. Development and validation of an in vivo Candida albicans biofilm denture model. Infect Immun 2010; 78: 3650-9.

[69] Rodrigues LR, Banat IM, van der Mei HC, Teixeira JA, Oliveira R. Interference in adhesion of bacteria and yeasts isolated from explanted voice prostheses to silicone rubber by rhamnolipid biosurfactants. J Appl Microbiol 2006; 100: 470-80.

[70] Lawrence EL, Turner IG. Materials for urinary catheters: a review of their history and development in the UK. Med Eng Phys 2005; 27: 443-53.

[71] Lamfon H, Porter SR, McCullough M, Pratten J. Susceptibility of Candida albicans biofilms grown in a constant depth film fermentor to chlorhexidine, fluconazole and miconazole. J Antimicrob Chemother 2004; 53: 383-5.

[72] Parkar SG, Flint SH, Brooks JD. Evaluation of the effect of cleaning regimes on biofilms of thermophilic bacilli on stainless steel. J Appl Microbiol 2004; 96: 110-6.

[73] Khardori N, Yassien M. Biofilms in device-related infections. J Ind Microbiol 1995; 15: 141-7.

[74] Donlan RM. Biofilms and device-associated infections. Emerg Infect Dis 2001; 7: 277-81.

[75] Kojic EM, Darouiche RO. Candida infections of medical devices. Clin Microbiol Rev 2004; 17: 255-67.

[76] Auler ME, Morreira D, Rodrigues FF, et al. Biofilm formation on intrauterine devices in patients with recurrent vulvovaginal candidiasis. Med Mycol 2010; 48: 211-6.

[77] Brown DH, Hilgers FJ, Irish JC, Balm AJ. Postlaryngectomy voice rehabilitation: state of the art at the millennium. World J Surg 2003; 27: 824-31.

[78] Pawar PV, Sayed SI, Kazi R, Jagade MV. Current status and future prospects in prosthetic voice rehabilitation following laryngectomy. J Cancer Res Ther 2008; 4: 186-91.

[79] Kasperbauer JL, Thomas JE. Voice rehabilitation after near-total laryngectomy. Otolaryngol Clin N Am 2004; 37: 655-77.

[80] Belforte G, Carello M, Miani C, Staffieri A. Staffieri tracheooesophageal prosthesis for voice rehabilitation after laryngectomy: an evaluation of characteristics. Med Biol Eng Comput 1998; 36: 754-60

[81] Calder N, MacAndie C, MacGregor F. Tracheoesophageal voice prostheses complications in north Glasgow. J Laryngol Otol 2006; 120: 487-91.

[82] Kress P, Schafer P, Schwerdtfeger FP. The custom-fit voice prosthesis, for treatment of periprosthetic leakage after tracheoesophageal voice restoration. Laryngo-Rhino-Otologie 2006; 85: 496-500.

[83] Bauters TGM, Moerman M, Vermeersch H, Nelis HJ. Colonization of voice prostheses by albicans and non-albicans Candida species. Laryngoscope 2002; 112: 708-12.

[84] Elving GJ, van der Mei HC, van Weissenbruch R, Busscher HJ, Albers FWJ. Comparison of the microbial composition of voice prosthesis biofilms from patients requiring frequent versus infrequent replacement. Ann Otol Rhinol Laryngol 2002; 111: 2003.

[85] Neu TR, Deboer CE, Verkerke GJ, et al. Biofilm development in time on a silicone voice prosthesis-a case-study. Microb Ecol Health Dis 1994; 7: 27-33

[86] Leunisse C, van Weissenbruch R, Busscher HJ, van der Mei HC, Albers FW. The artificial throat: a new method for standardization of in vitro experiments with tracheo-oesophageal voice prostheses. Acta Otolaryngol 1999; 119: 604-8.

[87] Leunisse C, van Weissenbruch R, Busscher HJ, van der Mei HC, Dijk F, Albers FW. Biofilm formation and design features of indwelling silicone rubber tracheoesophageal voice prostheses--an electron microscopical study. J Biomed Mater Res 2001; 58: 55663.

[88] Op de Coul BMR, Hilgers FJM, Balm AJM, Tan IB, van den Hoogen FJA, van Tinteren H. A decade of postlaryngectomy vocal rehabilitation in 318 patients. Arch Otolaryngol Head Neck Sur 2000; 126: 1320-8.

[89] Ramage G, Tomsett K, Wickes BL, López-Ribot JL, Redding SW. Denture stomatitis: a role for Candida biofilms. Oral Surg Oral Med Oral Pathol Oral Radiol Endod 2004; 98: 53-9.

[90] Webb BC, Thomas CJ, Willcox MDP, Harty DWS, Knox KW. Candida-associated denture stomatitis. Aetiology and management: a review. Part 1. Factors influencing distribution of Candida species in the oral cavity. Aust Dent J 1998; 43: 45-50.

[91] Webb BC, Thomas CJ, Willcox MDP, Harty DWS, Knox KW. Candida-associated denture stomatitis. Aetiology and management: a review. Part 2. Oral diseases caused by Candida species. Aust Dent J 1998; 43: 160-6. 
[92] Webb BC, Thomas CJ, Willcox MDP, Harty DWS, Knox KW. Candida-associated denture stomatitis. Aetiology and management: a review. Part 3. Treatment of oral candidosis. Aust Dent J 1998; 43: 244-9.

[93] Cousins BG, Allison HE, Doherty PJ, et al. Effects of a nanoparticulate silica substrate on cell attachment of Candida albicans. J Appl Microbiol 2007; 102: 757-65.

[94] Hou S, Burton EA, Simon KA, Blodgett D, Luk YY, Ren D. Inhibiting Escherichia coli biofilm formation by self-assembled monolayers of functional alkanethiols on gold. Appl Environ Microbiol 2007; 73: 4300-7.

[95] Vejborg RM, Klemm P. Blocking of bacterial biofilm formation by a fish protein coating. Appl Environ Microbiol 2008; 74: 3551-8.

[96] Hetrick EM, Schoenfisch MH. Reducing implant-related infections: active release strategies. Chem Soc Rev 2006; 35: 780-9.

[97] Schierholz JM. Physico-chemical properties of a rifampicinreleasing polydimethylsiloxane shunt. Biomaterials 1997; 18: 63541.

[98] Schierholz JM, Steinhauser H, Rump AFE, Berkels R, Pulverer G. Controlled release of antibiotics from biomedical polyurethanes: morphological and structural features. Biomaterials 1997; 18: 83944.

[99] Price JS, Tencer AF, Arm DM, Bohach GA. Controlled release of antibiotics from coated orthopedic implants. J Biomed Mater Res 1996; 30: 281-6.

[100] Kwok CS, Horbett TA, Ratner BD. Design of infection-resistant antibiotic-releasing polymers: II. Controlled release of antibiotics through a plasma-deposited thin film barrier. J Control Release 1999; 62: 301-11.

[101] Stigter M, Bezemer J, de Groot K, Layrolle P. Incorporation of different antibiotics into carbonated hydroxyapatite coatings on titanium implants, release and antibiotic efficacy. J Control Release 2004; 99: 127-37.

[102] Nava-Ortiz CAB, Burillo G, Concheiro A, et al. Cyclodextrinfunctionalized biomaterials loaded with miconazole prevent Candida albicans biofilm formation in vitro. Acta Biomat 2010; 6: 1398-404.

[103] Dowling DP, Betts AJ, Pope C, McConnell ML, Eloy R, Arnaud MN. Anti-bacterial silver coatings exhibiting enhanced activity through the addition of platinum. Surf Coat Tech 2003; 163: 63740.

[104] Radheshkumar C, Münstedt H. Antimicrobial polymers from polypropylene/silver composites- $\mathrm{Ag}^{+}$release measured by anode stripping voltametry. React Funct Polym 2006; 66: 780-8.

[105] Damm C, Münstedt H. Kinetic aspects of the silver ion release from antimicrobial polyamide/silver nanocomposites. Appl Phys A 2008; 91: 479-86.

[106] Poelstra KA, van der Mei HC, Gottenbos B, Grainger DW, van Horn JR, Busscher HJ. Pooled human immunoglobulins reduce adhesion of Pseudomonas aeruginosa in a parallel plate flow chamber. J Biomed Mater Res 2000; 51: 224-32.

[107] Rojas IA, Slunt JB, Grainger DW. Polyurethane coatings release bioactive antibodies to reduce bacterial adhesion. J Control Release 2000; 63: 175-89.

[108] Rediske AM, Koenig AL, Barekzi N, Cash Ameen L, Slunt JB, Grainger DW. Polyclonal human antibodies reduce bacterial attachment to soft contact lens and corneal cell surfaces. Biomaterials 2002; 23: 4565-72.

[109] Frost MC, Reynolds MM, Meyerhoff ME. Polymers incorporating nitric oxide releasing/generating substances for improved biocompatibility of blood-containing medical devices. Biomaterials 2005; 26: 1685-93.

[110] Nablo BJ, Prichard HL, Butler RD, Klitzman B, Schoenfisch MH. Inhibition of implant associated infections via nitric oxide release. Biomaterials 2005; 26: 6984-90.

[111] Shin JH, Schoenfisch MH. Improving the biocompatibility of in vivo sensors via nitric oxide release. Analyst 2006; 131: 609-15.

[112] Hetrick EM, Prichard HL, Klitzman B, Schoenfisch MH. Reduced foreign body response at nitric oxide-releasing subcutaneous implants. Biomaterials 2007; 28: 4571-80.

[113] Falagas ME, Fragoulis K, Bliziotis IA, Chatzinikolaou I. Rifampicin-impregnated central venous catheters: a meta-analysis of randomized controlled trials. J Antimicrob Chemother 2007; 59: 359-69.
[114] Pigno MA, Goldschmidt MC, Lemon JC. The efficacy of antifungal agents incorporated into a facial prosthetic PDMS elastomer. J Prosthet Dent 1994; 71: 295-300.

[115] Liang XM, Wang AF, Cao T, et al. Effect of cast molded rifampicin/silicone on Staphylococcus epidermidis biofilm formation. J Biomed Mater Res A 2006; 76: 580-8.

[116] Wu P, Grainger DW. Drug/device combinations for local drug therapies and infection prophylaxis. Biomaterials 2006; 27: 245067.

[117] Nikawa H, Ishida K, Hamada T, et al. Immobilization of octadecyl ammonium chloride on the surface of titanium and its effect on microbial colonization in vitro. Dent Mater J 2005; 24:570-82.

[118] Avent AG, Carpenter CN, Smith JD, Healy DM, Gilchrist T. The dissolution of silver-sodium-calcium-phosphate glasses for the control of urinary tract infections. J Non-Cryst Solids 2003; 328: 31-9.

[119] Atiyeh BS, Gunn W, Hayek SN. State of the art in burn treatment. World J Surg 2005; 29: 131-48.

[120] Roe D, Karandikar B, Bonn-Savage N, Gibbins B, Roullet JB. Antimicrobial surface functionalization of plastic catheters by silver nanoparticles. J Antimicrob Chemother 2008; 61: 869-76.

[121] Khare MD, Bukhari SS, Swan A, Spiers P, McLaren I, Myers J. Reduction of catheter-related colonisation by the use of a silver zeolite impregnated central vascular catheter in adult critical care. $\mathrm{J}$ Infect 2007; 54: 146-50.

[122] Kwakye-Awuah B, Williams C, Kenward MA, Radecka I. Antimicrobial action and efficiency of silver-loaded zeolite X. J Appl Microbiol 2008; 104: 1516-24.

[123] Tan S, Ouyang Y, Zhang L, Chen Y, Liu Y. Study on the structure and antibacterial activity of silver-carried zirconium phosphate. Mater Lett 2008; 62: 2122-4.

[124] Luo G, Tang J, He W, et al. Antibacterial effect of dressings containing multivalent silver ion carried by zirconium phosphate on experimental rat burn wounds. Wound Rep Reg 2008; 16: 800-4.

[125] Leder SB, Acton LM, Kmiecik J, Ganz C, Blom E. Voice restoration with the advantage tracheoesophgaeal voice prosthesis. Otolaryng-Head Neck 2005; 133: 681-4.

[126] Kress P, Schafer P, Schwerdtfeger FP. Clinical use of a voice prosthesis with a flap valve containing silver oxide (BlomSinger®Advantage), biofilm formation, in-situ lifetime and indication. Laryngo-Rhino-Otologie 2006; 85: 893-6.

[127] Wang H, Brown HR. Ultraviolet grafting of methacrylic acid and acrylic acid on high-density polyethylene in different solvents and the wettability of grafted high-density polyethylene. I. Grafting. J Polym Sci Pol Chem 2003; 42: 253-62.

[128] Pan B, Viswanathan K, Hoyle CE, Moore RB. Photoinitiated grafting of maleic anhydride onto polypropylene. J Polym Sci Pol Chem 2004; 42: 1953-62.

[129] Hsiue GH, Lee SD, Chang PCT, Kao CY. Surface characterization and biological properties study of silicone rubber membrane grafted with phospholipid as biomaterial via plasma induced graft copolymerization. J Biomed Mat Res 1998; 42: 134-47.

[130] Kyomoto M, Iwasaki Y, Moro T, et al. High lubricious surface of cobalt-chromium-molybdenum alloy prepared by grafting poly(2methacryloyloxyethyl phosphorylcholine). Biomaterials 2007; 28: 3121-30.

[131] Lópéz-Pérez PM, Marques AP, da Silva RMP, Pashkuleva I, Reis RL. Effect of chitosan membrane surface modification via plasma induced polymerization on the adhesion of osteoblast-like cells. J Mater Chem 2007; 17: 4064-71.

[132] Wang J, Liu X, Choi HS. Graft copolymerization kinetics of acrylic acid onto the poly(ethylene terepthalate) surface by atmospheric pressure plasma inducement. J Polym Sci Pol Phys 2008; 46: 1594 601.

[133] Zettsu N, Itoh H, Yamamura K. Surface functionalization of PTFE sheet through atmospheric pressure plasma liquid deposition approach. Surf Coat Tech 2008; 202: 5284-8.

[134] Lee SH, Hsiue GH, Kao CY. Preparation and characterization of a homobifunctional silicone rubber membrane grafted with acrylic acid via plasma-induced graft copolymerization. J Polym Sci Pol Chem 1996; 34: 141-8.

[135] Chang Y, Cheng TY, Shih YJ, Lee KR, Lai JY. Biofoulingresistance expanded poly(tetrafluoroethylene) membrane with a hydrogel-like layer of surface-immobilized poly(ethylene glycol) methacrylate for human plasma protein repulsions. J Membrane Sci 2008; 323: 77-84. 
[136] Young TH, Lu JN, Lin DJ, Chang CL, Chang HH, Cheng LP. Immobilization of L-lysine on dense and porous poly(vinylidene fluoride) surfaces for neuron culture. Desalination 2008; 234: 13443.

[137] Bae JS, Seo EJ, Kang IK. Synthesis and characterization of heparinized polyurethanes using plasma glow discharge. Biomaterials 1999; 20: 529-37.

[138] Malpass CA, Millsap KW, Sidhu H, Gower LB. Immobilization of an oxalate-degrading enzyme on silicone elastomer. J Biomed Mater Res 2002; 63: 822-9.

[139] Lin J, Qiu S, Lewis K, Klibanov AM. Bactericidal properties of flat surfaces and nanoparticles derivatized with alkylated polyethylenimines. Biotechnol Prog 2002; 18: 1082-6.

[140] De Prijck K, De Smet N, Coenye T, Nelis HJ, Schacht E. Prevention of Candida albicans biofilm formation by covalently bound dimethylaminoethylmethacrylate and polyethylenimine. Mycopathologia 2010; in press.

[141] De Prijck K, De Smet N, Rymarczyk-Machal M, et al. Candida albicans biofilm formation on peptide functionalised polydimethylsiloxane. Biofouling 2010; 26: 269-75.
[142] Kenawy ER, Abdel-Hay FI, Abou El-Magd A, Mahmoud Y. Biologically active polymers: VII. Synthesis and antimicrobial activity of some crosslinked copolymers with quaternary ammonium and phosphonium groups. React Funct Polym 2006; 66: 419-29.

[143] Kenawy ER, Mahmoud YAG. Biologically active polymers, Synthesis and antimicrobial activity of some linear copolymers with quaternary ammonium and phosphonium groups. Macromol Biosci 2003; 3: 107-16.

[144] Oosterhof JJH, Buijssen KJDA, Busscher HJ, van der Laan BFAM, van der Mei HC. Effects of quaternary ammonium silane coatings on mixed fungal and bacterial biofilms on tracheoesophageal shunt prostheses. Appl Environ Microbiol 2006; 72: 3673-7.

[145] Everaert EPJM, van der Mei HC, Busscher HJ. Adhesion of yeasts and bacteria to fluoro-alkylsiloxane layers chemisorbed on silicone rubber. Colloid Surface B 1998; 10: 179-90.

[146] Lin J, Qiu S, Lewis K, Klibanov AM. Mechanism of bactericidal and fungicidal activities of textiles covalently modified with alkylated polyethylenimine. Biotechnol Bioeng 2003; 83: 168-72.

Received: November 16, 2010

(C) Coenye et al.; Licensee Bentham Open .

This is an open access article licensed under the terms of the Creative Commons Attribution Non-Commercial License (http://creativecommons.org/licenses/by$\mathrm{nc} / 3.0 /$ ), which permits unrestricted, non-commercial use, distribution and reproduction in any medium, provided the work is properly cited. 